\title{
Forest Restoration in the State of Rio De Janeiro: Adherence to Legislation
}

\author{
Ciro José Ribeiro de Moura ${ }^{1,2}$ (D), Henrique Seixas Barros $^{1}$ (D), \\ Flavio Dias Wanderley Valente ${ }^{1}$ (D), Victor Abreu Araújo ${ }^{1}$ (D), \\ Julia Kishida Bochner ${ }^{1}$ (D) \\ ${ }^{1}$ Instituto Estadual do Ambiente - INEA, Rio de Janeiro/RJ, Brasil \\ ${ }^{2}$ Programa de Pós-graduação em Engenharia Ambiental, Universidade Federal do Rio de Janeiro - UFRJ, \\ Rio de Janeiro/RJ, Brasil
}

\begin{abstract}
This study evaluated forest restoration projects filed at the state environmental agency of Rio de Janeiro (Inea), regarding the requirements contained in the Resolution No 36/2011. Legal, technical, environmental and ecological parameters of 65 restoration projects in the design and implementation phases were analyzed. Only 29\% of the projects met the requirements of Resolution No 36/2011. The low compliance with the requirements of the resolution evidences the lack of knowledge of the current regulations in the state of Rio de Janeiro by the technical users of the system. This condition implies a longer time of environmental licensing. Recently, Inea has revoked Res. No 36/2011 through Res. No 143/2017, which, in addition to simplifying the presentation of restoration projects, gave rise to the State System for Monitoring and Evaluation of Forest Restoration - SEMAR.
\end{abstract}

Keywords: forest restoration, PRAD, Inea Resolution No 36/2011, Inea Resolution No $143 / 2017$. 


\section{INTRODUCTION}

Despite the increasing efforts to restore degraded areas, ecological restoration is still a relatively recent scientific discipline (Aronson et al., 2011). In this sense, scientific advances are necessary for restoration programs to be truly effective (Brancalion et al., 2010), which means that the results of new studies need to be incorporated into forest restoration projects.

The current paradigm based primarily on ecosystem knowledge and species growth capacity (Hobbs \& Harris, 2001) is not sufficient to ensure the success of forest restoration efforts.

From this perspective, forest restoration is adopted as a compensatory measure within the environmental licensing system (Lopes \& Ribeiro, 2016).

In general, new enterprises demand an authorisation for the removal of native vegetation in order to install their infrastructure. Associated with the mechanisms of environmental compensation, deforestation seeks to reconcile economic interests such as the expansion of productive activity, the maintenance of environmental services, the conservation of biodiversity and the preservation of the landscape.

However, current environmental compensation mechanisms need to be improved to resolve issues such as the time lag between the planting establishment of a new forest, the high degree of uncertainty in restoration processes, and the application of the economic value established in the environmental compensation measures (Maron et al., 2012).

Although initiatives aimed at forest restoration have been practiced regularly in the state of Rio de Janeiro for more than 25 years, such as the Mutirão Reforestation Project, an initiative of the Municipal Government of Rio de Janeiro, they struggle against technical, political and market failures (Richards, 1999). However, some of the failures on forest restoration practice are in its origin, during the design phase of the project, which disregards the local characteristics and apply methods independently of the ecology patterns of each region (Kollmann et al., 2016).

With the intention of improving the quality of the restoration projects submitted to the Rio de Janeiro State Environmental Institute - Inea -, Resolution Inea No 143 was published on June 14, 2017 (Rio de Janeiro, 2017), establishing the State System for Monitoring and Evaluation of Forest Restoration (SEMAR). This resolution revoked Inea Resolution No 36/2011 (Rio de Janeiro, 2011), which established the term of reference (TR) for the elaboration of forest restoration projects (PRAD).

In this sense, this work brings together an unprecedented diagnosis of the situation of forest restoration projects in the state of Rio de Janeiro in light of the main normative instrument, Inea Resolution No $36 / 2011$, presenting the minimum content to be contemplated by forest restoration projects. This resolution provided a blueprint to a precise diagnosis of the target area of the project, the adoption of methods compatible with the site, the indication of species being consonant with the physical, and the chemical and biological characteristics of the area, allowing a detailed description of the field operations and a timetable for the proposed goals.

The objective of this paper was to evaluate the level of adoption and adequacy of the projects in terms of Inea Resolution No 36/2011, with the overall aim to generate an analysis of the effectiveness and understanding of this regulation, based on the analysis of projects registered within the Forest Service Management GESEF -, providing new information and perspectives on the management of forest restoration in the state of Rio de Janeiro.

\section{MATERIAL AND METHODS}

\subsection{Study area}

The state of Rio de Janeiro, located in the southeast of Brazil, is composed of 92 municipalities organized in eight administrative regions, covering an area of $43,696,054 \mathrm{~km}^{2}$. The highly diverse landscape consists of mountains and lowlands, headlands, lagoons, bays and tropical forests (IBGE, 2010).

\subsection{Data collection and analysis}

The collection of data was limited to actions derived from commitments to recompose the legal reserve or environmental compensation on the Atlantic Forest context in Rio de Janeiro, under the light of Res. Inea No 36/2011. For this, a survey of 300 administrative processes was carried out in the Forest Service Management - GESEF / Inea. Of these, 65 processes 
presented projects of forest restoration (PRAD), motivated by mechanisms of environmental compensation linked to the licensing of economic activities and the approval of legal reserves (RL), granted by Inea between 2005 and 2014, and regulated by the Inea Resolution No 36 of July 8, 2011. Analysis of the periods prior to 2011 was carried out with the purpose of providing an assessment of the impact of the normative instrument in the pre- and post-resolution environment.

Regardless of whether the motivation is RL registration or environmental compensation, the preparation of the PRAD should follow the term of reference published through the Resolution Inea No 36.

For analysis and verification of the adequacy level to the legislation of the administrative processes and their respective projects, the systematization of the data was adopted in the project phase, subdivided into two sub-phases, namely 1 (diagnosis) and 2 (silvicultural). The legal parameters, as well as technical, environmental and ecological assessments, are presented in Table 1. From this systematization, it was possible to carry out the descriptive diagnosis of the situation of the restoration projects underway in Inea. After obtaining the data, the analyses were carried out using spreadsheets in Microsoft Excel.

Table 1. Data collection framework.

\begin{tabular}{|c|c|}
\hline Sub-phase diagnosis & Sub-phase silviculture \\
\hline Legal parameters & Technical parameters \\
\hline PRAD motivation & Plant spacing \\
\hline $\begin{array}{l}\text { Attendance to Res. 36/2011 } \\
\text { (Rio de Janeiro, 2011) }\end{array}$ & Seedling size \\
\hline Technical parameters & Soil fertilization \\
\hline Project area & $\begin{array}{l}\text { Use of water-holding } \\
\text { polymer }\end{array}$ \\
\hline Direction of slopes & Forest protection \\
\hline Average slope & Use of mechanization \\
\hline Actual vegetation cover & Ecological parameters \\
\hline Presence of water bodies & Seedling origin \\
\hline Georeferencing & Ecological groups \\
\hline Soil analysis & Seed dispersion syndrome \\
\hline \multicolumn{2}{|l|}{ Project timeline } \\
\hline \multicolumn{2}{|l|}{ Environmental parameters } \\
\hline \multicolumn{2}{|l|}{ Average rainfall } \\
\hline \multicolumn{2}{|l|}{ Average temperature } \\
\hline \multicolumn{2}{|l|}{ Phytophysiognomy } \\
\hline \multicolumn{2}{|l|}{ Relief description } \\
\hline \multicolumn{2}{|l|}{ Proximity to forest patches } \\
\hline $\begin{array}{l}\text { Presence of naturally } \\
\text { regenerated areas }\end{array}$ & \\
\hline
\end{tabular}

\section{RESULTS}

Out of the 65 PRADs analyzed, only 22\% met the recommendations established by Resolution No 36/2011. Considering only PRADs after 2011, when the resolution was launched, the level of compliance with the legislation remains relatively low, $30 \%$ (Table 2).

Regarding the motivation of the restoration commitment, of the 65 PRADs analyzed, 79\% were derived from environmental compensation commitments linked to the environmental licensing of potentially or effectively polluting activities and $11 \%$ of the legal reserve (RL) recomposition commitments, as recommended by the Brazilian Forest Code. The rest was motivated by voluntary initiatives or Inea notifications, which are not under the regulation of the Resolution No 36/2011.

The projects analyzed covered 2.702 hectares (ha), with an average size of 51.0 ha per PRAD, ranging from 0.03 to over 700 hectares, which reflects the heterogeneity of the projects in process. The indications of the direction of slopes, average slope and the presence of water bodies in the projects were considered unsatisfactory, making it impossible to analyze and/or extrapolate the results, as the supplied data were not standardized.

In relation to the content of the protocoled projects, $49 \%$ presented geo-referenced planialtimetric maps that consider the three-dimensional model of the terrain, as required by the TR of Resolution No 36/2011. About $37 \%$ of the projects presented soil analysis results; in $50 \%$ of the PRADs, this information was not presented, and about $13 \%$ of the projects did not even mention this requirement (Table 3 ).

The predominant land cover in the PRAD areas analyzed is marked by the occurrence of exotic grasses, appearing in $47.7 \%$ of the total projects. Secondary forests and other land use types followed, each accounting

Table 2. Proportion of attendance to the Resolution Inea 36/2011 (Rio de Janeiro, 2011) in the analyzed administrative processes (AP).

\begin{tabular}{|ccc}
$\begin{array}{c}\text { Year of the } \\
\text { administrative } \\
\text { process }\end{array}$ & $\mathbf{N}^{\mathbf{0}}$ of projects & $\begin{array}{c}\text { \% compliance } \\
\text { with the } \\
\text { Res. } \mathbf{N}^{\mathbf{0}} \\
\mathbf{3 6 / 2 0 1 1}\end{array}$ \\
\hline Before 2011 & 34 & 15 \\
\hline After 2011 & 31 & 29 \\
\hline Total (2005-2014) & 65 & 22 \\
\hline
\end{tabular}


for $16.9 \%$. These results reinforce data indicating that $81 \%$ of the area of the state of Rio de Janeiro is deforested (Fundação SOS Mata Atlântica, 2014).

The project timeline was presented in $50.7 \%$ of the PRADs analyzed, showing negligence regarding planning and predictability in restoration programs.

The results indicate that the main forest phytophysiognomy object of the PRADs analyzed was the Ombrophilous Dense Forest (FOD) in the lowland, submontane and montane formations. Information on the characterization of forest phytophysiognomy was omitted in $20 \%$ of the analyzed projects.

Data on average rainfall were available in about $50 \%$ of the projects, with average rainfall of around $1,500 \mathrm{~mm} /$ year. Temperature data were provided in $44 \%$ of the projects, with an average value of $22^{\circ} \mathrm{C}$, ranging between 15 and $40^{\circ} \mathrm{C}$.

The PRAD analysis indicated that $63 \%$ of the areas were located less than 100 meters away from forest fragments; however, only $31 \%$ of the projects considered the presence of natural regeneration as an element to be managed in the restoration effort.

The total area planting method was considered in $83 \%$ of the projects, while natural regeneration was indicated as a strategy in $9 \%$ of the projects studied. In $8 \%$ of the projects, the planting methodology was not described.

Planting methods usually applied two spacings, namely $2 \times 2 \mathrm{~m}$ and $3 \times 2 \mathrm{~m}$, indicated in 24 and 18 PRADs, respectively. Other spacings, e.g. $2 \times 2.5 \mathrm{~m}, 2.5 \times 2.5 \mathrm{~m}$, $4 \times 4 \mathrm{~m}$, were used infrequently.

Only $12 \%$ of the projects considered the requirement contained in the reference term of the Inea Resolution No.36/2011 in relation to the minimum seedling size of $60 \mathrm{~cm}$. Across all analyzed projects, $88 \%$ did not even consider this requirement, and there is no indication of understanding or adopting the regulation.

The application of soil fertilizer to the plantations was considered in $80 \%$ of the PRADs; however, coverage fertilization was only considered in $58 \%$ of the projects. In most projects, the commercial fertilizer NPK was predominantly used, followed by limestone, manure, simple superphosphate, natural phosphate, potassium chloride, ammonium sulphate, and urea (Table 4).
Table 3. Main results of the analysis of compliance of sub-phase 1 with Resolution Inea 36/2011 (Rio de Janeiro, 2011) in administrative processes between the years 2005 and 2014 .

\begin{tabular}{|c|c|}
\hline Sub-phase diagnosis & $\begin{array}{c}\text { Level of } \\
\text { compliance }(\%)\end{array}$ \\
\hline \multicolumn{2}{|l|}{ Legal parameters } \\
\hline Attendance to Res. $36 / 2011$ & 29.0 \\
\hline \multicolumn{2}{|l|}{ Technical parameters } \\
\hline Project area & 100.0 \\
\hline Soil analysis & 37.0 \\
\hline Project timeline & 50.7 \\
\hline \multicolumn{2}{|l|}{ Environmental parameters } \\
\hline Average rainfall & 50.0 \\
\hline Average temperature & 44.0 \\
\hline Phytophysiognomy & 80.0 \\
\hline Proximity to forest patches & 63.0 \\
\hline
\end{tabular}

Table 4. Main results of the analysis of compliance of sub-phase 2 with Resolution Inea 36/2011 (Rio de Janeiro, 2011) in administrative processes between the years 2005 and 2014 .

\begin{tabular}{lc}
\multicolumn{1}{c}{ Sub-phase silviculture } & $\begin{array}{c}\text { Level of compliance } \\
(\mathbf{\%})\end{array}$ \\
Technical parameters & \\
Plant spacing & 80.0 \\
Seedling size & 12.0 \\
Soil fertilisation & 80.0 \\
Use of water-holding polymer & 23.0 \\
Forest protection & 32.0 \\
Use of mechanisation & 20.0 \\
\hline
\end{tabular}

The use of herbicides to control exotic grasses, which were indicated in half of the PRADs, was considered low, with only $5 \%$ of the projects applying them.

Forest protection measures in the analyzed PRADs were represented by fences (32\%) and fire lines (29\%) as the most usual strategies. In $52.5 \%$ of the projects, no protection measures were taken, and no information on the adoption of protective measures was provided.

Throughout the analyzed projects, mechanization was considered low, $20 \%$ on average, representing mowing, plant spot opening or seedling transport.

Only in a small number of the projects ( 15 out of 65 ; $23 \%)$, water-holding polymer gel was applied.

Ecological restoration with the use of autochthonous species was the standard and represented by $80 \%$ of the protocoled projects. Among the species used in restoration programs, there was a relative balance in the 
proportion of species with anemochory and zoochory dispersion syndromes. It is worth mentioning that in $15 \%$ of the projects, this information was not presented.

The successional stage (pioneer and non-pioneer species) of the plants used in the restoration projects was reported in $90 \%$ of the projects.

Based on the results of the evaluation of adherence and understanding of Resolution № 36/2011 (Rio de Janeiro, 2011), workshops, documentary reviews and monitoring of field projects were carried out, which resulted in the creation of the State System for Monitoring and Evaluation of Restoration - SEMAR -, now regulated by Resolution Inea No 143/2017 (Rio de Janeiro, 2017). In this sense, SEMAR standardized the project models, technical report and forest restoration commitment deadline, and created the monitoring and evaluation protocol.

\section{DISCUSSION}

The data presented here indicated the low level of knowledge about restoration practices and adherence to Inea Resolution No 36/2011, since only about one third of the projects submitted fully met the TR requirements. The formulation of public regulations by itself is not sufficient to correct policy failures, and a communication strategy plan must be considered during design and implementation.

Public policies should provide the guidelines, rules and procedures for relations between public power and the society. In this sense, the creation of the TR, object of Inea Resolution № 36/2011, served as a guideline and positioned the state as a protagonist, reducing bureaucracy and diminishing subjectivity in environmental licensing and compensation processes.

However, the low level of adherence to the regulation, evidenced in the forest restoration projects analyzed, requires the state to seek ways to redirect its policy, making it more effective and maximizing results to correct existing flaws.

The implementation of public policies can be considered as the apex of the environmental policy process. Policy success should ultimately be assessed by its impacts in practice, but despite many institutional initiatives, implementation failures are recurrent and are not unique to any of the public-sector entities.
Understanding the mistakes and successes in the implementation of policies and realizing the responsibilities and interests of the main actors involved in the implementation of policies, as well as opening channels of discussion of possible solutions to the goals and results of policies, are elements that guarantee the success of environmental policies (Jordan, 1999).

The impact of the creation of Resolution № 36/2011 can be considered incipient when compared to the period prior to the publication of the resolution, given the unsatisfactory number of projects that present the set of information required by the current legislation at the time. The attendance level below 30\% shows that there were flaws in the understanding of the rules by users of the system and also in the disclosure and effectiveness of communication by Inea.

The consequence of not complying with the regulations implies a longer time in the administrative process of the project, generating delays in the evaluation of projects and in all licensing systems, besides generating rework for the entrepreneur and the public service. It should be noted that if the project does not include all the information required by current regulations, it cannot be approved by the public server.

Regarding the technical criteria evaluated in the diagnostic and silviculture sub-phases, these were inconsistent, since they did not present the minimally necessary information required. The format of the projects presentation was not systematized, and the volume of information was sometimes excessive and inaccurate, making it difficult for the environmental agency technicians to analyze them, generating rework and delays.

The quality of the projects can still be questioned, as they disregarded the interaction of the areas to be restored with their surroundings. As an example, $63 \%$ of the projects were located near primary forest fragments, and only $31 \%$ considered the management of elements of natural regeneration as a restoration strategy, with only $9 \%$ of the projects using this technique effectively.

This shows that, although new strategies have been developed and improved in recent years (i.e. seed rain management, litter transposition, seedling bank activation, nucleation, use of artificial perches, among others), the recurrent technique used in restoration projects in the Atlantic Forest of Rio de Janeiro continues to be the planting of native species across the entire area to be 
restored. In this sense, this choice significantly increases the implementation and maintenance costs, and the projects may become unfeasible from the financial point of view over time (Rodrigues et al., 2009).

A critical point was observed in relation to the technical specification of the minimum size of the seedlings, and $88 \%$ of the analyzed projects did not comply with the regulations. Currently, the requirement of a minimum seedling size of $60 \mathrm{~cm}$ has been revoked with the new resolution that instituted SEMAR.

Soil analysis was performed in less than $40 \%$ of the projects analyzed. The lack of analysis as well as fertilization recommendations can be justified with the small number of soil analysis laboratories in the state. Another factor may be the scarcity of data on nutrient accumulation of native forest species.

Herbicides were applied only in 5\% of the projects, setting a low level of use of this resource in silvicultural practices in the forest restoration projects implemented in the state. In addition, exotic grasses were present in approximately half of the projects, and their control is usually a limiting factor in restoration projects (Hooper et al., 2004; Brancalion et al., 2009). The control of competing grasses is fundamental to avoid compromising the success of the restoration and to eliminate unnecessary risks (Souza \& Batista, 2004).

Another source of direct impact on the costs of a project is the observed mortality rate, which implies the replanting of new seedlings. In this sense, the use of practices that reduce this risk is desirable, for example, the application of insecticides for ant control to prevent leafcutter ant attacks on seedlings and the use of water-holding polymer gel, which increases the availability of water to the seedlings at the beginning of their development in the field.

Analyzing the ecological parameters to infer the trajectory of the forest succession process, the use of native species was verified, and the ecological succession patterns were compatible with the phytophysiognomies of the Atlantic Forest (Alves et al., 2005; Oliveira, 2007).

The characterization of phytophysiognomy, among others, is a fundamental element in the elaboration of a forest restoration project, since it is based on the definition of a reference ecosystem that will guide the recomposition of the degraded environment (Hobbs \& Harris, 2001; Ruiz-Jaen \& Aide, 2005). Therefore, the absence of this information, which was observed in $20 \%$ of the cases, may compromise the quality of the projects presented.

In addition to the selection of species appropriate to the site characteristics and their respective proportions in the different successional stages, the success of reforestation programs also depends on preventive and protective measures. However, the adoption of strategies such as fencing and fire lines was not even indicated in approximately half of the evaluated projects, compromising their success because of competition with cattle and the frequency of forest fires.

It should also be considered that the reproductive strategies of the plants should be evaluated when proposals are made to combine species to reach final communities in restored areas, with the purpose of avoiding reproductive isolation, leading to the failure of restoration programs (Castro et al., 2007).

For zoochory species, the dispersion depends on the movement patterns of the animals, influencing plant recruitment. These effects also depend, in part, on the microhabitats where the seeds are deposited and their influences on seedling growth and mortality (Rother et al., 2013).

Overcoming the biological and site-specific filters that prevent or hinder succession progression towards a forest ecosystem is the challenge imposed on formulators and implementers of restoration projects. Therefore, observing and assimilating the signals the environment itself reveals are fundamental steps to ensure the success of restoration efforts.

\section{CONCLUSIONS}

The low level of compliance with the resolution and, consequently, the increase in the time of the procedure required a repositioning of the state to obtain greater publicity and clarity for its regulatory mechanisms.

In fact, the number of projects complied with Resolution No 36/2011 evidenced the lack of knowledge by the private technical forest sector in terms of the regulations in the state of Rio de Janeiro.

We observed a low level of mechanization as well as a low use of new technologies and innovative approaches in forest restoration in Rio de Janeiro. The underlying causes may be the training of professionals at the universities or even the inexpressive agricultural sector 
and or the incipience of a strong forestry culture in the state of Rio de Janeiro.

In this sense, the adoption of technologies and techniques that increase the success of restoration actions should be stimulated through public policies, inducing systematization and regulation, promoting their wide dissemination.

\section{ACKNOWLEDGEMENTS}

The authors thanks to all those involved in the covenant 1900.0082864.13.3 version 1.1 established between Petróleo Brasileiro S/A, Instituto Estadual do Ambiente and the Sociedade Eco-Atlântica Eco-Atlântica.

\section{SUBMISSION STATUS}

Received: 6 dec., 2017

Accepted: 26 apr., 2018

\section{CORRESPONDENCE TO}

\section{Ciro José Ribeiro de Moura}

Gerência do Serviço Florestal, Instituto Estadual do Ambiente - INEA, Av. Marechal Floriano, 45, $3^{\circ}$ andar, Centro, CEP 20080-901, Rio de Janeiro, RJ, Brasil e-mail: cirojrm@hotmail.com, ciro.inea@gmail. com

\section{REFERENCES}

Alves S, Zaú A, Oliveira RR, Lima DF, Moura CJR. Sucessão florestal e grupos ecológicos em Floresta Atlântica de encosta, Ilha Grande, Angra dos Reis/RJ. Revista de Ciências da Vida 2005; 25(1): 26-32.

Aronson J, Durigan G, Brancalion PHS. Conceitos e definições correlatos à ciência e à prática da restauração ecológica. IF Séries Registros 2011; 44: 1-38.

Brancalion PHS, Isernhagen I, Machado RP, Christoffoleti PJ, Rodrigues RR. Seletividade dos herbicidas setoxidim, isoxaflutol e bentazon a espécies arbóreas nativas. Pesquisa Agropecuária Brasileira 2009; 44(3): 251-257. http://dx.doi. org/10.1590/S0100-204X2009000300005.

Brancalion PHS, Rodrigues RR, Gandolfi S, Kageyama PY, Nave AG, Gandara FB et al. Instrumentos legais podem contribuir para a restauração de florestas tropicais biodiversas. Revista Árvore 2010; 34(3): 455-470. http:// dx.doi.org/10.1590/S0100-67622010000300010.
Castro CC, Martins SV, Rodrigues RR. A focus on plant reproductive biology in the context of forest restoration. In: Rodrigues, R.R., Martins, S.V., Gandolfi, S. editors. High diversity forest restoration in degraded areas. New York: Nova Science Publishers; 2007.

Fundação SOS Mata Atlântica. Atlas dos remanescentes florestais da Mata Atlântica: período 2012-2013. São Paulo: Fundação SOS Mata Atlântica; 2014.

Hobbs RJ, Harris JA. Restoration ecology: repairing the earth's ecosystems in the new millennium. Restoration Ecology 2001; 9(2): 239-246. http://dx.doi.org/10.1046/ j.1526-100x.2001.009002239.x.

Hooper ER, Legendre P, Condit R. Factors affecting community composition of forest regeneration in deforested, abandoned land in Panama. Ecology 2004; 85(12): 3313-3326. http://dx.doi.org/10.1890/03-0655.

Instituto Brasileiro de Geografia e Estatística - IBGE. Censo Demográfico 2010: características da população e dos domicílios. Rio de Janeiro: IBGE; 2010.

Jordan A. The implementation of EU environmental policy: a policy problem without a political solution? Environment and Planning. C, Government \& Policy 1999; 17(1): 69-90. http://dx.doi.org/10.1068/c170069.

Kollmann J, Meyer ST, Bateman R, Conradi T, Gossner MM, Mendonça MS Jr et al. Integrating ecosystem functions into restoration ecology recent advances and future directions. Restoration Ecology 2016; 24(6): 722 730. http://dx.doi.org/10.1111/rec.12422.

Lopes LCP, Ribeiro JCJ. O papel da avaliação de impacto ambiental para adoção de medidas compensatórias. Revista de Direito Ambiental e Socioambientalismo 2016; 2(1): 148-169. http://dx.doi.org/10.26668/ IndexLawJournals/2525-9628/2016.v2i1.976.

Maron M, Hobbs RJ, Moilanen A, Matthews JW, Christie K, Gardner TA et al. Faustian bargains? Restoration realities in the context of biodiversity offset policies. Biological Conservation 2012; 155: 141-148. http://dx.doi. org/10.1016/j.biocon.2012.06.003.

Oliveira RR. Mata Atlântica, paleoterritórios e história ambiental. Ambiente \& Sociedade 2007; 10(2): 11-23. http://dx.doi.org/10.1590/S1414-753X2007000200002.

Richards M. Internalizando as externalidades da silvicultura tropical: uma revisão dos mecanismos inovadores de financiamento e incentivo. Londres: Overseas Development Institute; 1999.

Rio de Janeiro. Resolução INEA PRES no. 36 de 08 de julho de 2011. Diário Oficial do Estado do Rio de Janeiro [online], Rio de Janeiro, RJ (2011) [cited 2017 Dec 6]. Available from: http://www.inea.rj.gov.br/cs/groups/ public/documents/document/zwew/mdy2/ edisp/ inea0066935.pdf

Rio de Janeiro. Resolução INEA PRES no. 143 de 14 de junho de 2017. Diário Oficial do Estado do Rio de 
Janeiro [online], Rio de Janeiro, RJ (2017) [cited 2017 Dec 6]. Available from: http://www.inea.rj.gov.br/Portal/ Agendas/BIODIVERSIDADEEAREASPROTEGIDAS/ ServicoFlorestal/ProjetoDeRestauracaoFlorestal/index. htm\&lang=PT-BR\#ad-image- 0

Rodrigues R, Lima AF, Gandolfi S, Nave AG. On the restoration of high diversity forests: 30 years of experience in the Brazilian Atlantic. Biological Conservation 2009; 142(6): 1242-1251. http://dx.doi.org/10.1016/j.biocon.2008.12.008.

Rother DC, Jordano P, Rodrigues RR, Pizo MA. Demographic bottlenecks in tropical plant regeneration: a comparative analysis of causal influences. Perspectives in Plant Ecology, Evolution and Systematics 2013; 15(2): 86-96. http://dx.doi. org/10.1016/j.ppees.2012.12.004.

Ruiz-Jaen MC, Aide TM. Restoration success: how is it being measured? Restoration Ecology 2005; 13(3), 569577. http://dx.doi.org/10.1111/j.1526-100X.2005.00072.x.

Souza FM, Batista JLF. Restoration of seasonal semideciduous forests in Brazil: influence of age and restoration design on forest structure. Forest Ecology and Management 2004; 191(1-3): 185-200. http://dx.doi.org/10.1016/j. foreco.2003.12.006. 